\title{
Comparison of the Bactericidal Effect of Slightly Acidic Hypochlorous Water with That of Conventional Sterilizers
}

\section{Soli, Kevin Webby}

Laboratory of Food Hygienic Chemistry, Division of Food Science and Biotechnology, Department of Bioscience and Biotechnology, Graduate School of Bioresource and Bioenvironmental Sciences, Kyushu University

\section{Motomatsu, $\mathrm{Ai}$}

Laboratory of Food Hygienic Chemistry, Division of Food Science and Biotechnology, Department of Bioscience and Biotechnology, Graduate School of Bioresource and Bioenvironmental Sciences, Kyushu University

\section{Yoshizumi, Asako}

Laboratory of Food Hygienic Chemistry, Division of Food Science and Biotechnology, Department of Bioscience and Biotechnology, Graduate School of Bioresource and Bioenvironmental Sciences, Kyushu University

\section{Yamakawa, Mami}

Laboratory of Food Hygienic Chemistry, Division of Food Science and Biotechnology, Department of Bioscience and Biotechnology, Graduate School of Bioresource and Bioenvironmental Sciences, Kyushu University

他

https://doi.org/10.5109/18842

出版情報：九州大学大学院農学研究院紀要. 55 (2)，pp. 275-280，2010-10-29. Faculty of Agriculture, Kyushu University バージョン :

権利関係: 


\title{
Comparison of the Bactericidal Effect of Slightly Acidic Hypochlorous Water with That of Conventional Sterilizers
}

\section{Kevin Webby SOLI ${ }^{1}$, Ai MOTOMATSU ${ }^{1}$, Asako YOSHIZUMI ${ }^{1}$, Mami YAMAKAWA ${ }^{1}$, Tomoko MISHIMA ${ }^{1}$, Ken-ichi HONJOH and Takahisa MIYAMOTO*}

Laboratory of Food Hygienic Chemistry, Division of Food Science and Biotechnology, Department of Bioscience and Biotechnology, Faculty of Agriculture, Kyushu University, Fukuoka 812-8581, Japan

(Received June 30, 2010 and accepted July 9, 2010)

\begin{abstract}
The bactericidal effect of slightly acidic hypochlorous water (SAHW) on Salmonella Enteritidis, Escherichia coli, Staphylococcus aureus, Listeria monocytogenes, and Bacillus cereus, as well as some bacterial strains isolated from fresh lettuce was evaluated. Viable counts of all tested bacterial samples decreased immediately after treatment by SAHW. Most bacterial cells with the exception of B. cereus, and S. aureus were not culturable on TSA after treatment by 1 to $30 \mathrm{mg} / \mathrm{L}$ SAHW. Likewise, Pseudomonas sp., and Flavobacterium or Xanthomonas sp., Kurthia sp., Micrococcus sp., and Corynebacterium or Microbacterium sp. were not culturable on TSA after treatment by $30 \mathrm{mg} / \mathrm{L}$ SAHW. Viable counts of $S$. aureus, E. coli, Flavobacterium or Xanthomonas sp., and Pseudomonas sp. showed a 5 to $6 \mathrm{log} \mathrm{cfu} / \mathrm{mL}$ reduction at day 0 and maintained a count of less than $1 \log \mathrm{cfu} / \mathrm{mL}$ from day 1 to day 7 following treatment by $30 \mathrm{mg} / \mathrm{L}$ SAHW. Sodium hypochlorite $(\mathrm{NaOCl}, 0.5-1.0 \mathrm{mg} / \mathrm{L})$ decreased the viable counts of $S$. Enteritidis to less than the lower limit of detection, $1 \log \mathrm{cfu} / \mathrm{mL}$, from day 1 to day 7 following treatment by $1 \mathrm{mg} / \mathrm{L}$. $\mathrm{NaOCl}$ was not sufficient at $0.5-0.75 \mathrm{mg} / \mathrm{L}$ in reducing viable counts of $S$. Enteritidis because of a 2 to 5 log $\mathrm{cfu} / \mathrm{mL}$ increase from day 2 to day 5 due to recovery from injury. Initial counts of $S$. Enteritidis after hydrogen peroxide $\left(\mathrm{H}_{2} \mathrm{O}_{2}, 1000-2000 \mathrm{mg} / \mathrm{L}\right)$ treatment slowly decreased over time to less than $1 \mathrm{log} \mathrm{cfu} / \mathrm{mL}$ after day 2. Treatment by 1750 to $2000 \mathrm{mg} / \mathrm{L} \mathrm{H}_{2} \mathrm{O}_{2}$ has sufficient bactericidal activity on $S$. Enteritidis cells, however, at a higher concentration compared to $\mathrm{NaOCl}$ or SAHW. SAHW decreased viability of $S$. Enteritidis immediately with higher reduction counts in 1,5 , and $30 \mathrm{mg} / \mathrm{L}$ from day 0 to day 7 unlike $\mathrm{NaOCl}$ and $\mathrm{H}_{2} \mathrm{O}_{2}$.
\end{abstract}

\section{INTRODUCTION}

Increasing demand for fresh, healthy and convenient foods has led to a continuous growth in the fresh-cut fruit and vegetable industry (Rico et al., 2007). Fruit and vegetable consumption is an important part of a healthy diet for consumers worldwide, but eating uncooked produce is not risk free (Rahman et al., 2010). Fresh-cut produce is highly susceptible to microbial contamination from a number of sources including postharvest handling and processing. Salmonella Enteritidis, pathogenic Escherichia coli, Staphylococcus aureus, Listeria monocytogenes, and Bacillus cereus have been reported as common food-borne pathogens that are of major public health concern (Mead et al., 1999). In Japan, 2007 statistics by the Japanese Ministry of Health, Labor and Welfare reported an estimated 1000 outbreaks of food-borne illness comprising about 4,000 cases associated with composite ready-to-eat foods and about 1000 cases with vegetable and vegetable products (Soli et al., 2010).

Decontamination of fresh-cut produce plays an important role in the preservation of food quality and safety of consumption (Nguyen-The and Carlin, 1992). Unfortunately, the 'fresh' nature of produce restricts the

\footnotetext{
${ }^{1}$ Laboratory of Food Hygienic Chemistry, Division of Food Science and Biotechnology, Department of Bioscience and Biotechnology, Graduate School of Bioresource and Bioenvironmental Sciences, Kyushu University

* Corresponding author (E-mail: tmiyamot@agr.kyushu-u.ac.jp)
}

use of thermal decontamination as a means of prevention, or elimination of risks associated with produce, or reduction of pathogenic bacteria to an acceptable level (Soli et al., 2010). In Japan, sodium hypochlorite ( $\mathrm{NaOCl}$ ) solution (100-200 mg/L of available chlorine), acidic electrolyzed water (AcEW) (20-60 mg/L of available chlorine) and slightly acidic electrolyzed water (SlAEW) (10$30 \mathrm{mg} / \mathrm{L}$ of available chlorine) have been authorized for use with food by the Japanese Ministry of Health and Welfare (Koide et al., 2009).

SlAEW has attracted growing interest concerning studies in washing and sanitizing treatments for the removal or inactivation of pathogens on food, as well as food contact surfaces (Suzuki et al., 2005; Ono, Miyake, and Yamashita, 2005; Yamashita et al., 2005; Okamoto., 2006; Koide et al., 2009). Slightly acidic electrolyzed water or slightly acidic hypochlorous water (SAHW) (10-30 mg/mL of available chlorine) (Soli et al., 2010) contains mainly hypochlorous acid (HOCl; 97\%), which has been shown to have strong antimicrobial activity (Yoshifumi, 2003). The application of SAHW minimizes human health and safety issues from $\mathrm{Cl}_{2}$ off-gassing, reduces corrosion of surfaces and limits phototoxic side effects while maximizing the application of HOCl species (Guentzel et al., 2008), thus an alternative to using sodium hypochlorite (a widely used food product disinfectant) or hydrogen peroxide $\left(\mathrm{H}_{2} \mathrm{O}_{2}\right)$.

The objectives of this study were to (1) investigate the bactericidal effect of SAHW against some Gramnegative and Gram-positive pathogens, such as Salmonella Enteritidis, Escherichia coli, Staphylococcus 
aureus, Listeria monocytogenes, and Bacillus cereus and against bacterial strains isolated from lettuce, a leafy vegetable being the prime ingredient in ready-made salads, and (2) comparing the bactericidal effect of SAHW with that of $\mathrm{NaOCl}$ and $\mathrm{H}_{2} \mathrm{O}_{2}$ solution.

\section{MATERIALS AND METHODS}

\section{Bacterial strains}

Salmonella Enteritidis IFO 3313, Escherichia coli IFO 3301, and Staphylococcus aureus IFO 3060 were purchased from Institute for Fermentation, Osaka, Japan. Bacillus cereus JCM 2152 was obtained from Japan Collection of Microorganisms, Wako, Saitama, Japan. Bacillus cereus emetic and diarrheal strains, Escherichia coli O157:H7, Listeria monocytogenes serotype 1/2a and $4 \mathrm{~b}$ strains were provided by Fukuoka City Institute for Hygiene and the Environment, Fukuoka, Japan. Flavobacterium or Xanthomonas sp., Pseudomonas sp., Kurthia sp., Micrococcus sp., and Corynebacterium or Microbacterium sp. were isolated from lettuce and identified in our laboratory by using general biochemical tests (Gibbs and Skinner, 1966).

\section{Preparation of SAHW}

Fresh SAHW was generated using the Purester MP-240E Unit (Morinaga Milk Industry, Japan) at a production capacity of $240 \mathrm{~L} / \mathrm{h}$. The Purester unit electrolyzes about 2 to $6 \%$ of hydrochloric acid ( $\mathrm{HCl}$ ) in a nondiaphragm electrolytic cell generating a highly concentrated hypochlorous acid ( $\mathrm{HOCl}$ ), which is diluted by tap water, thus, producing SAHW of available chlorine concentration of 10 to $30 \mathrm{mg} / \mathrm{L}$ with $\mathrm{pH} 5.0$ to 6.5. Further dilutions using deionized water were carried out to produce concentrations lower than $10 \mathrm{mg} / \mathrm{L}$.

\section{Bacterial culture and bactericidal test}

Stock cultures of each pathogenic strain and bacterial isolates from lettuce were transferred into tryptic soy broth (TSB, Becton Dickinson) and incubated at $35^{\circ} \mathrm{C}$ for $24 \mathrm{~h}$. Following incubation, cells were harvested from $10 \mathrm{~mL}$ of each culture by centrifugation at $5000 \times \mathrm{g}$ for $5 \mathrm{~min}$ at $4{ }^{\circ} \mathrm{C}$ and washed with sterile deionized water. The cells were then suspended in $10 \mathrm{~mL}$ solution of SAHW (0.1-30 mg/L of available chlorine concentra- tion) at a final cell concentration of $10^{7}-10^{8} \mathrm{cfu} / \mathrm{mL}$. The cell suspensions were kept at $25^{\circ} \mathrm{C}$ for 5 min to determine minimal bactericidal concentration. For determination of the long-term effects of SAHW, the cells were suspended in $10 \mathrm{~mL}$ solution of SAHW $(0.1-30 \mathrm{mg} / \mathrm{L}$ of available chlorine concentration) at a final cell concentration of $10^{7}-10^{8} \mathrm{cfu} / \mathrm{mL}$, and were kept at $25^{\circ} \mathrm{C}$ for 7 days. For comparison of the bactericidal effects of SAHW with those of $\mathrm{NaOCl}$ and $\mathrm{H}_{2} \mathrm{O}_{2}$ on $S$. Enteritidis, $S$. Enteritidis cells were suspended in $10 \mathrm{~mL}$ solution of SAHW (0.1-30 mg/L of available chlorine concentration), $\mathrm{NaOCl}(0.5-1.0 \mathrm{mg} / \mathrm{L})$, or $\mathrm{H}_{2} \mathrm{O}_{2}(1000-2000 \mathrm{mg} / \mathrm{L})$ at a final cell concentration of $10^{7}-10^{8} \mathrm{cfu} / \mathrm{mL}$. The cell suspensions were kept at $25^{\circ} \mathrm{C}$ for 5 or 7 days. Aliquots of the suspensions were withdrawn at suitable intervals, serially diluted $10-$ folds with sterile saline and $0.1 \mathrm{~mL}$ of diluted suspension were surface spread onto tryptic soy agar (TSA, Becton Dickinson). After incubation at $37^{\circ} \mathrm{C}$ for $48 \mathrm{~h}$, viable counts were determined.

\section{RESULTS}

\section{Bactericidal activity of SAHW on some pathogenic bacteria}

Bactericidal activity of SAHW (1-30 mg/L of available chlorine) on pure cultures of some Gram-negative $(S$. Enteritidis, E. coli) and Gram-positive ( $S$. aureus, $L$. monocytogenes, $B$. cereus) pathogenic and non-pathogenic bacteria is shown in Table 1. SAHW-treated cell suspensions $\left(10^{7}-10^{8} \mathrm{cfu} / \mathrm{mL}\right)$ of each bacterium were cultured and enumerated on TSA. Viable counts of all the pathogenic bacteria decreased immediately by $10^{1}-10^{5}$ folds after treatment by $1.0 \mathrm{mg} / \mathrm{L}$ SAHW. As the chlorine concentration of SAHW was increased to 5, 10, and $30 \mathrm{mg} / \mathrm{L}$, the viable counts further decreased. Most bacterial cells with the exception of $B$. cereus, and $S$. aureus were less than the lower limit of detection $(<10 \mathrm{cfu} / \mathrm{mL})$ by the plating method on TSA after treatment by 10 to $30 \mathrm{mg} / \mathrm{L}$ SAHW. Two strains of B. cereus (JCM 2152, diarrheal) had counts of $1.0 \times 10^{2}$ and $6.0 \times 10^{1} \mathrm{cfu} / \mathrm{mL}$ respectively after treatment by $30 \mathrm{mg} / \mathrm{L}$ SAHW. The bactericidal effect of treatment by $30 \mathrm{mg} / \mathrm{L}$ SAHW is sufficient in reducing the viable counts of $S$. Enteritidis, $E$. coli, S. aureus, L. monocytogenes, and B. cereus.

Table 1. Bactericidal activity of SAHW on some pathogenic and non-pathogenic bacteria

\begin{tabular}{|c|c|c|c|c|c|}
\hline \multirow{3}{*}{ Bacteria } & \multicolumn{5}{|c|}{ Viable counts (cfu/mL) } \\
\hline & \multirow{2}{*}{ Control } & \multicolumn{4}{|c|}{ After treatment with SAHW at (mg/L) } \\
\hline & & 1 & 5 & 10 & 30 \\
\hline B. cereus JCM 2152 & $1.3 \times 10^{7}$ & $5.6 \times 10^{6}$ & $1.1 \times 10^{4}$ & $9.7 \times 10^{3}$ & $1.0 \times 10^{2}$ \\
\hline B. cereus emetic strain & $1.7 \times 10^{7}$ & $1.0 \times 10^{4}$ & $5.5 \times 10^{3}$ & $1.7 \times 10^{3}$ & $<10$ \\
\hline B. cereus diarrheal strain & $1.4 \times 10^{7}$ & $1.4 \times 10^{4}$ & $1.5 \times 10^{3}$ & $1.2 \times 10^{3}$ & $6.0 \times 10^{1}$ \\
\hline L. monocytogenes serotype $1 / 2 \mathrm{a}$ & $4.6 \times 10^{7}$ & $3.5 \times 10^{2}$ & $<10$ & $<10$ & $<10$ \\
\hline L. monocytogenes serotype $4 \mathrm{~b}$ & $1.6 \times 10^{8}$ & $2.1 \times 10^{3}$ & $<10$ & $<10$ & $<10$ \\
\hline S. aureus IFO 3060 & $7.0 \times 10^{7}$ & $3.1 \times 10^{5}$ & $6.6 \times 10^{4}$ & $9.4 \times 10^{2}$ & $<10$ \\
\hline E. coli IFO 3301 & $4.1 \times 10^{7}$ & $2.2 \times 10^{3}$ & $6.0 \times 10^{1}$ & $<10$ & $<10$ \\
\hline E. coli O157:H7 & $3.6 \times 10^{7}$ & $1.0 \times 10^{3}$ & $<10$ & $<10$ & $<10$ \\
\hline S. Enteritidis IFO 3313 & $1.4 \times 10^{8}$ & $1.1 \times 10^{6}$ & $<10$ & $<10$ & $<10$ \\
\hline
\end{tabular}


Table 2. Bactericidal activity of SAHW on some bacterial isolates from fresh lettuce

\begin{tabular}{lccccc}
\hline \multirow{2}{*}{\multicolumn{1}{c}{ Bacteria }} & \multicolumn{5}{c}{ Viable counts (cfu/mL) } \\
\cline { 2 - 6 } & Control & \multicolumn{4}{c}{ After treatment with SAHW at (mg/L) } \\
\cline { 2 - 5 } & & 1 & 5 & 10 & 30 \\
\hline Flavobacterium or Xanthomonas sp. & $2.1 \times 10^{8}$ & $5.3 \times 10^{6}$ & $1.1 \times 10^{4}$ & $9.7 \times 10^{3}$ & $<10$ \\
Pseudomonas sp. & $1.1 \times 10^{8}$ & $1.5 \times 10^{5}$ & $5.5 \times 10^{3}$ & $<10$ & $<10$ \\
Kurthia sp. & $1.3 \times 10^{8}$ & $2.1 \times 10^{5}$ & $<10$ & $<10$ & $<10$ \\
Micrococcus sp. & $1.2 \times 10^{8}$ & $<10$ & $<10$ & $<10$ & $<10$ \\
Corynebacterium or Microbacterium sp. & $1.1 \times 10^{8}$ & $<10$ & $<10$ & $<10$ & $<10$ \\
\hline
\end{tabular}

\section{Bactericidal activity of SAHW on some bacterial isolates from fresh lettuce}

Bactericidal activity of SAHW (0.1-30 mg/L of available chlorine) on some bacterial isolates from fresh lettuce is shown in Table 2. SAHW-treated cell suspensions $\left(10^{7}-10^{8} \mathrm{cfu} / \mathrm{mL}\right)$ of each bacterium were cultured and enumerated on TSA. Viable counts of all the bacterial isolates from lettuce decreased by $10^{2}-10^{3}$ folds after treatment by $1.0 \mathrm{mg} / \mathrm{L}$ SAHW. As the chlorine concentration of SAHW was increased to 5,10 , and $30 \mathrm{mg} / \mathrm{L}$, the viable counts further decreased. Flavobacterium or Xanthomonas sp. had viable counts of $9.7 \times 10^{3}$ after treatment by $10 \mathrm{mg} / \mathrm{L}$ SAHW, however, Pseudomonas sp., Kurthia sp., Micrococcus sp., and Corynebacterium sp. or Microbacterium sp. were less than $10 \mathrm{cfu} / \mathrm{mL}$ on TSA after treatment by 10-30 mg/L SAHW. Treatment by $30 \mathrm{mg} / \mathrm{L}$ SAHW has sufficient bactericidal activity on all the bacterial isolates from fresh lettuce.

\section{Long-term bactericidal effect of SAHW on some bacterial strains}

Bactericidal effects of SAHW (0.1-30 mg/L of available chlorine) were determined for 7 days on some bacterial strains that were relatively resistant to SAHW. The changes of viable counts enumerated on TSA of some bacterial strains in SAHW solution with different available chlorine concentration are shown in Fig. 1.

Viable counts of B. cereus JCM 2152 decreased immediately after treatment by SAHW above $5 \mathrm{mg} / \mathrm{L}$. Following treatment by $30 \mathrm{mg} / \mathrm{L}$ SAHW, viable counts of $B$. cereus JCM 2152 had a 5 log reduction at day 0 and had 2 and $5 \log$ difference compared to 5 and $1 \mathrm{mg} / \mathrm{L}$ SAHW, respectively. The viable counts further decreased to below the lower limit of detection after day 1 and day 3 for 30 , and $5 \mathrm{mg} / \mathrm{L} \mathrm{SAHW.} \mathrm{In} \mathrm{contrast,} \mathrm{viable} \mathrm{counts} \mathrm{of}$ $0.5 \mathrm{mg} / \mathrm{L}$ SAHW-treated samples increased by 1 log from day 1 to 7 . The bactericidal effect of treatment by $30 \mathrm{mg} / \mathrm{L}$ SAHW seems sufficient in reducing the viable counts of $B$. cereus JCM 2152

Viable counts of $S$. aureus IFO 3060 decreased immediately after treatment by SAHW above $10 \mathrm{mg} / \mathrm{L}$. Following treatment by $30 \mathrm{mg} / \mathrm{L}$ SAHW, viable counts of $S$. aureus had more than $7 \log$ reduction at day 0 with 2 and $4 \mathrm{log}$ difference compared to 10 and $5 \mathrm{mg} / \mathrm{L}$ SAHW, respectively. The viable counts further decreased below the lower limit of detection after day 1 and day 3 for 10 , and $5 \mathrm{mg} / \mathrm{L}$ SAHW. The bactericidal effect of treatment by SAHW of more than $10 \mathrm{mg} / \mathrm{L}$ seems sufficient in reducing the viable counts of $S$. aureus. (a) B. cereus JCM 2152

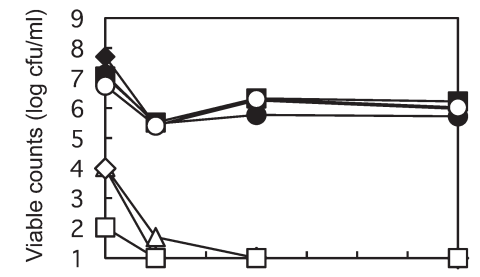

(b) S. aureus IFO 3060

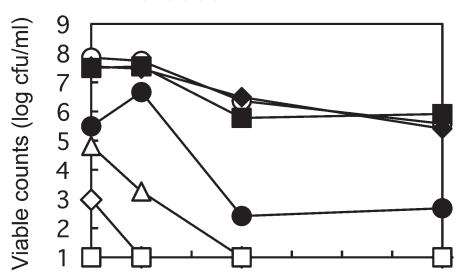

(c) E. coli IFO 3301

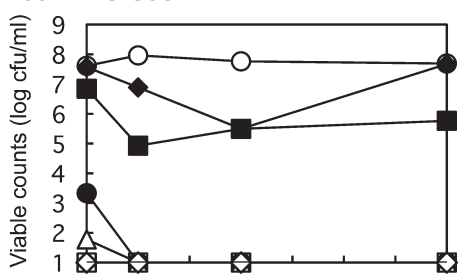

(d) Flavobacterium or Xanthomonas sp.

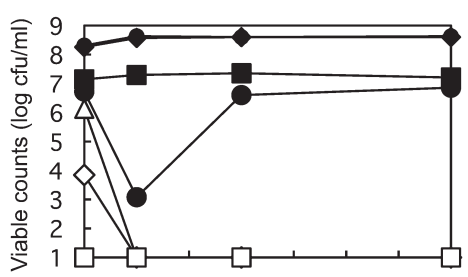

(e) Pseudomonas sp.

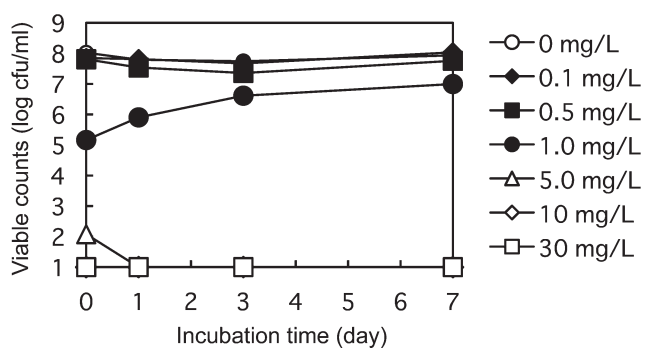

Fig. 1. Long-term bactericidal effect of SAHW on some bacterial strains.

Bactericidal effects of SAHW (0.1-30 mg/L of available chlorine) were determined for 7 days on some bacterial strains that were relatively resistant to SAHW.

Symbols: $\bigcirc, 0 \mathrm{mg} / \mathrm{L} ; \bullet, 0.1 \mathrm{mg} / \mathrm{L} ; \square, 0.5 \mathrm{mg} / \mathrm{L} ; \bigcirc, 1.0 \mathrm{mg} / \mathrm{L} ; \triangle$ $5.0 \mathrm{mg} / \mathrm{L} ; \diamond, 10 \mathrm{mg} / \mathrm{L} ; \square, 30 \mathrm{mg} / \mathrm{L}$ 
Viable counts of $E$. coli IFO 3301 decreased immediately after treatment by SAHW above $1 \mathrm{mg} / \mathrm{L}$. Following treatment by $10 \mathrm{mg} / \mathrm{L}$ SAHW, viable counts of $E$. coli IFO 3301 had 7 log reduction at day 0 and with 1 and $3 \log$ difference compared to 5 and $1 \mathrm{mg} / \mathrm{L}$ SAHW, respectively. The viable counts further decreased below the lower limit of detection after day 1 for 1 and $5 \mathrm{mg} / \mathrm{L}$ SAHW. In contrast, viable counts of $0.1 \mathrm{mg} / \mathrm{L}$ SAHW-treated cells decreased to $5.5 \log \mathrm{cfu} / \mathrm{mL}$ at day 3 and increased by $2.5 \mathrm{log}$ from day 3 to 7 suggesting that the recovery of the injured cells were generated in the presence of SAHW at the sub-lethal concentration. The bactericidal effect of treatment by $30 \mathrm{mg} / \mathrm{L}$ SAHW seems sufficient in reducing the viable counts of $E$. coli IFO 3301.

Viable counts of Flavobacterium or Xanthomonas sp. decreased by 7 log immediately after treatment by SAHW at $30 \mathrm{mg} / \mathrm{L}$. Following treatments by 5 and $10 \mathrm{mg} / \mathrm{L}$ SAHW, viable counts immediately decreased to 6 and $4 \log$ cfu/mL respectively, further reduction to less than the lower detection limit at day 1, and did not increase at day 7 . In the presence of $1 \mathrm{mg} / \mathrm{L}$ SAHW, viable counts decreased by $5 \log$ but increased by $4 \log$ at day 3 , indicating the recovery of the injured cells in the presence of SAHW at the sub-lethal concentration. The bactericidal effect of treatment by $30 \mathrm{mg} / \mathrm{L}$ SAHW seems sufficient in reducing the viable counts of Flavobacterium or Xanthomonas sp. isolated from lettuce.

Viable counts of Pseudomonas sp. decreased immediately after treatment by SAHW above $5 \mathrm{mg} / \mathrm{L}$. Following treatment by $5 \mathrm{mg} / \mathrm{L}$ SAHW, viable counts of Pseudomonas sp. had $6 \log$ reduction at day 0 with 3 and $6 \log$ difference compared to 1 and $0.5 \mathrm{mg} / \mathrm{L}$ SAHW, respectively. The viable counts further decreased to below the lower limit of detection after day 1 for $5 \mathrm{mg} / \mathrm{L}$ SAHW. In contrast, viable counts of $1 \mathrm{mg} / \mathrm{L}$ SAHWtreated cells immediately decreased to $5 \log \mathrm{cfu} / \mathrm{mL}$ at day 0 but gradually increased by $2 \log$ from day 0 to 7 , suggesting that the recovery of the injured cells were generated in the presence of SAHW at the sub-lethal concentration.

\section{Comparison of bactericidal effect of NaOCl on Salmonella Enteritidis}

Bactericidal effects of SAHW were compared with those of $\mathrm{NaOCl}$ and $\mathrm{H}_{2} \mathrm{O}_{2}$ on $S$. Enteritidis. Figure 2 shows the changes of viable counts of $S$. Enteritidis after suspension in $\mathrm{NaOCl}, \mathrm{H}_{2} \mathrm{O}_{2}$ and $\mathrm{SAHW}$ at various concentrations.

Viable counts of $S$. Enteritidis decreased immediately after treatment by $\mathrm{NaOCl}$, however, recovery of the culturability of $S$. Enteritidis was evident after day 1 and 2 for 0.5 and $0.75 \mathrm{mg} / \mathrm{L} \mathrm{NaOCl}$, respectively. There was a $5.5 \mathrm{log}$ increase in $0.75 \mathrm{mg} / \mathrm{L} \mathrm{NaOCl}$-treated cells from day 2 to day 5 compared to a $2 \log \mathrm{cfu} / \mathrm{mL}$ increase of cells treated with $0.5 \mathrm{mg} / \mathrm{L} \mathrm{NaOCl}$.

Bactericidal effect of $\mathrm{H}_{2} \mathrm{O}_{2}$ (1000-2000 mg/L) was determined on $S$. Enteritidis for 5 days. The initial viable counts of all the $\mathrm{H}_{2} \mathrm{O}_{2}$-treated cell suspensions of $S$. Enteritidis was about $8 \log \mathrm{cfu} / \mathrm{mL}$. The counts slowly decreased over time in the order of 2000, 1750, 1250, (a) $\mathrm{NaOCl}$

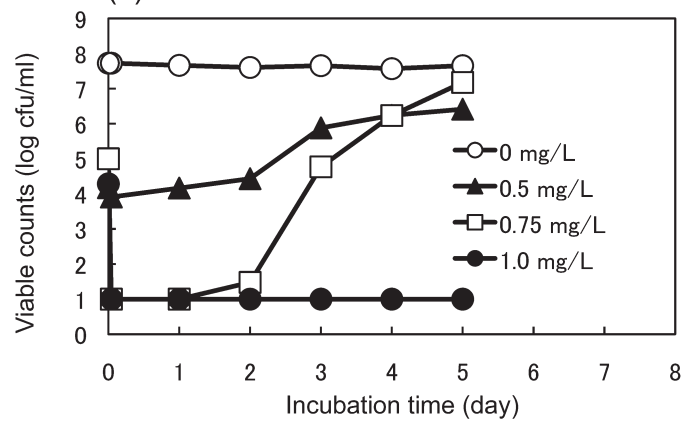

(b) $\mathrm{H}_{2} \mathrm{O}_{2}$

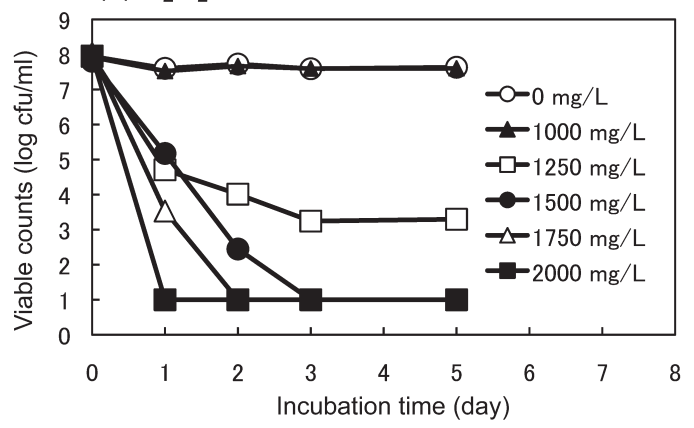

(c) SAHW

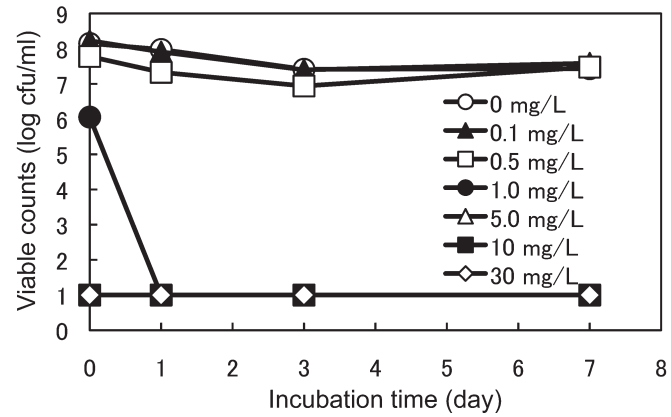

Fig. 2. Changes of viable counts of $S$. Enteritidis incubated in $\mathrm{NaOCl}, \mathrm{H}_{2} \mathrm{O}_{2}$, and $\mathrm{SAHW}$ at various concentrations.

$S$. Enteritidis cells were suspended in $10 \mathrm{~mL}$ solution of (a) $\mathrm{NaOCl}(0.5-1.0 \mathrm{mg} / \mathrm{L})$, (b) $\mathrm{H}_{2} \mathrm{O}_{2}(1000-2000 \mathrm{mg} / \mathrm{L})$, or (c) SAHW (0.1-30 mg/L of available chlorine concentration) at a final cell concentration of $10^{7}-10^{8} \mathrm{cfu} / \mathrm{mL}$. The cell suspensions were kept at $25^{\circ} \mathrm{C}$ for 5 or 7 days. Aliquots of the suspensions were withdrawn at suitable intervals, and viable counts were determined by the conventional plating method using TSA. Symbols are indicated in each figure.

and $1000 \mathrm{mg} / \mathrm{L}$. After day 2, counts of $2000 \mathrm{mg} / \mathrm{L}$, and $1750 \mathrm{mg} / \mathrm{L} \mathrm{H}_{2} \mathrm{O}_{2}$-treated cells were less than $10 \mathrm{cfu} / \mathrm{mL}$, the lower limit of detection. Treatment by 1750 to $2000 \mathrm{mg} / \mathrm{L} \mathrm{H}_{2} \mathrm{O}_{2}$ has sufficient bactericidal effect on $S$. Enteritidis cells, however, at a higher concentration compared to $\mathrm{NaOCl}$ or SAHW.

Viable counts of $S$. Enteritidis decreased immediately after treatment by SAHW above $5 \mathrm{mg} / \mathrm{L}$. Higher reduction of viable counts were evident in 5 , and $30 \mathrm{mg} / \mathrm{L}$ SAHW-treated samples from day 0 to day 7 . Compared to $\mathrm{NaOCl}$, there was not much generation of the injuredbut-recoverable cells at the sub-lethal SAHW concentration. The bactericidal effect of treatment by 5 to $30 \mathrm{mg} / \mathrm{L}$ SAHW seems sufficient in reducing the viable counts of $S$. Enteritidis. 


\section{DISCUSSION}

Pathogenic bacteria can contaminate raw agricultural produce through various pathways; therefore there is a need for effective decontamination of fresh produce. Decontamination of produce plays an important role in the preservation of food quality and safety of consumption (Nguyen-The and Carlin, 1992). Unfortunately, the 'fresh' nature of produce restricts the use of thermal decontamination (Soli et al., 2010). Washing produce with tap water cannot completely remove pathogenic and naturally occurring bacteria, therefore, promoting the development of new non-thermal sterilizers such as electrolyzed water to eliminate pathogenic bacteria on fresh produce (Guentzel et al., 2008). Among electrolyzed water, SAHW has attracted attention in regard to washing and sanitizing treatments for the removal or inactivation of pathogens on food.

Our study showed that SAHW (30 mg/L of available chlorine) has sufficient bactericidal effect on pure cultures of some Gram-negative (S. Enteritidis, E. coli) and Gram-positive (S. aureus, L. monocytogenes, B. cereus) pathogenic bacteria as well as on some bacterial strains (Flavobacterium or Xanthomonas sp., Pseudomonas sp., Kurthia sp., Micrococcus sp., Corynebacterium or Microbacterium sp.) isolated from fresh lettuce (Tables 1 and 2). Viable counts of all tested bacteria decreased immediately after treatment by SAHW.

Counts of all the pathogenic bacteria decreased by 1-5 log after treatment by $1 \mathrm{mg} / \mathrm{L}$ SAHW and further decreased as the available chlorine concentration of SAHW was increased to $30 \mathrm{mg} / \mathrm{L}$. Most bacterial cells with the exception of $B$. cereus, and $S$. aureus were not culturable on TSA after treatment by 10 to $30 \mathrm{mg} / \mathrm{L}$ SAHW. Although B. cereus JCM 2152 had counts of $1.0 \times 10^{2} \mathrm{cfu} /$ $\mathrm{mL}$ after treatment by $30 \mathrm{mg} / \mathrm{L}$ SAHW, the counts further decreased to below the lower limit of detection $(10 \mathrm{cfu} / \mathrm{mL})$ after day 1 . Population of all the bacterial isolates from lettuce decreased by $2-3 \log$ after treatment by $1 \mathrm{mg} / \mathrm{L}$ SAHW and further decreased as the chlorine concentration of SAHW was increased to $30 \mathrm{mg} / \mathrm{L}$. Predominant bacteria in fresh lettuce such as Pseudomonas sp., Flavobacterium or Xanthomonas sp., Kurthia sp., Micrococcus sp., and Corynebacterium or Microbacterium sp. were not culturable on TSA after treatment by $30 \mathrm{mg} / \mathrm{L}$ SAHW. SAHW also had sufficient bactericidal activity on $B$. cereus (diarrheal, emetic), and $E$. coli O157:H7 immediately after the treatment at $30 \mathrm{mg} / \mathrm{L}$ (Table 1). Following treatment by $30 \mathrm{mg} / \mathrm{L}$ SAHW, viable counts of $B$. cereus (diarrheal) decreased by $5 \log \mathrm{cfu} / \mathrm{mL}$ (data not shown). The counts further decreased to less than the lower limit of detection after day 1 similar to B. cereus JCM 2152 (Fig. 1). After treatment by $30 \mathrm{mg} / \mathrm{L}$ SAHW, viable counts of $B$. cereus (emetic) had a $7 \mathrm{log} \mathrm{cfu} / \mathrm{mL}$ reduction at day 0 . Treatment by $30 \mathrm{mg} / \mathrm{L}$ SAHW was very effective on $B$. cereus (emetic) from day 0 to day 7 maintaining viable counts less than $1 \log \mathrm{cfu} / \mathrm{mL}$ (data not shown). Viable counts of $E$. coli O157:H7 decreased immediately after treatment by SAHW (Table 1). Bactericidal activity of $5 \mathrm{mg} / \mathrm{L}$ SAHW was potent on $E$. coli O157:H7 than $E$. coli IFO 3301 from day 0 to day 7 maintaining viable counts less than 1 log cfu/mL (data not shown). Although the concentration of SAHW in the surrounding environment of some Gram-negative bacteria in food is sublethal such as lower than $1 \mathrm{mg} / \mathrm{L}$, some cells became injured-but-recoverable and recovered culturability after incubation for a few days (Fig. 1). However, the level of recovery seemed lower than that of the injured-butrecoverable cells generated in the presence of $\mathrm{NaOCl}$ (Fig. 2). These results indicated that long-term SAHW treatment above $5 \mathrm{mg} / \mathrm{L}$ is effective on reducing both viable and pathogenic bacterial counts in food and foodprocessing environment.

SAHW has better bactericidal effects on $S$. Enteritidis after 5 days as compared to conventional sterilizers, $\mathrm{NaOCl}$ and $\mathrm{H}_{2} \mathrm{O}_{2}$ solution (Fig. 2). The main chlorine sanitizer that has long been recognized and has a high disinfection efficacy in the food industry is NaOCl (100200 mg/L) (Dychdala, 2001; Takano and Yokoyama, 2001). In our study, viable counts of $S$. Enteritidis decreased immediately after treatment with $\mathrm{NaOCl}$, however, recovery of culturability of $S$. Enteritidis was evident after day 1 for both 0.5 , and $0.75 \mathrm{mg} / \mathrm{L} \mathrm{NaOCl}$. There was a further 2 to $5 \mathrm{log}$ increase of viable counts for $\mathrm{NaOCl}-$ treated samples from day 2 to day 5 , thus, 0.5 to $0.75 \mathrm{mg} / \mathrm{L}$ $\mathrm{NaOCl}$ is not sufficient in reducing viable counts of $S$. Enteritidis even though the level of concentration was manageable. It is well known in the food industry that if the concentration of $\mathrm{NaOCl}$ in the surrounding environment of Gram-negative bacteria in food is sub-lethal, the cells that were injured-but-recoverable will show regrowths after incubation for a few days. $\mathrm{H}_{2} \mathrm{O}_{2}$ is currently classified as GRAS (generally recognized as safe) for use in food products but has not yet been approved as an antimicrobial wash for produce (Sapers, 2001). Acceptable uses include that of bleaching agent, oxidizing and reducing agent, and antimicrobial. Lin et al. (2002) reported that the treatment of lettuce with 20000 $\mathrm{mg} / \mathrm{L}(2 \%) \mathrm{H}_{2} \mathrm{O}_{2}$ at $50{ }^{\circ} \mathrm{C}$ reduced $E$. coli $\mathrm{O} 157: \mathrm{H} 7$ and $L$. monocytogenes by 4 and 3 logs respectively. In our study, initial counts ( $8 \log \mathrm{cfu} / \mathrm{mL}$ ) of $S$. Enteritidis after $\mathrm{H}_{2} \mathrm{O}_{2}$ treatment slowly decreased over time in the order of $2000,1750,1250$, and $1000 \mathrm{mg} / \mathrm{L}$ (Fig.2). Treatment by 1750 to $2000 \mathrm{mg} / \mathrm{L}_{2} \mathrm{O}_{2}$ has sufficient bactericidal effect on day 2 and 1, respectively on $S$. Enteritidis cells, however, at a higher concentration compared to $\mathrm{NaOCl}$ or SAHW. The results indicated that longer treatment time is required for effective decontamination of bacteria by $\mathrm{H}_{2} \mathrm{O}_{2}$. On the other hand, SAHW-treated $S$. Enteritidis immediately decreased with higher reduction counts in 1,5 , and $30 \mathrm{mg} / \mathrm{L}$ available chlorine concentation and there were few injured-but-recoverable cells from day 0 to day 7 unlike $\mathrm{NaOCl}$ and $\mathrm{H}_{2} \mathrm{O}_{2}$.

Okamoto et al. (2006) reported that the important characteristic of SLAEW is the potential to lower the residual available chlorine in vegetables after the disinfection treatment compared to other chlorine sanitizers while Koide et al. (2009) reported that SlAEW would reduce 
its available chlorine when exposed to light and air. Since the available chlorine concentration of SlAEW or SAHW in our case, is originally low (10-30 mg/L), they suggested to having a constant flow rate of SlAEW by the electrolysis apparatus during the treatment to stabilize the available chlorine level and consequently the disinfection efficacy.

In conclusion, the results of this study indicated that $30 \mathrm{mg} / \mathrm{L}$ SAHW effectively reduces the population of $S$. Enteritidis, E. coli, S. aureus, L. monocytogenes, and $B$. cereus as well as bacterial strains of Flavobacterium or Xanthomonas sp., Pseudomonas sp., Kurthia sp., Micrococcus sp., Corynebacterium or Microbacterium sp. isolated from fresh lettuce by more than 5 log immediately after treatment. Treatment by $30 \mathrm{mg} / \mathrm{L}$ SAHW seems to be a promising non-thermal disinfection method of food and agricultural produce for both Gram-negative and positive bacteria. Moreover, use of SAHW will allow reduction of the amount of free chlorine used for disinfection of fresh-cut produce by the food industry.

\section{ACKNOWLEDGMENT}

This work was supported by a grant from the Ministry of Agriculture, Forestry and Fisheries of Japan (Research project for ensuring food safety from farm to table DI-7201). The authors are grateful to Dr. Toyohiko Doi (Morinaga Milk Industry) for providing the Purester ${ }^{\circledR}$ MP-240E Unit.

\section{REFERENCES}

Dychdala, G. R. 2001 Chlorine and chlorine compounds. In S. S. Block (Ed.), "Disinfection, sterilization, and preservation", (5th ed.) USA: Lippincott Williams and Wilkins, pp. 135-138

Gibbs, B. M and P. A. Skinner, 1966 Identification methods for microbiologists (part A), Academic Press, London pp. $59-64$

Guentzel, J. L., K. L. Lam, M. A. Callan, S. A. Emmons and V. L. Dunham 2008 Reduction of bacteria on spinach, lettuce, and surfaces in food service areas using neutral electrolyzed oxidizing water. Food Microbiol., 25: 36-41

Issa-Zacharia, A., Y. Kamitani, K. Morita and K. Iwasaki 2010 Sanitization potency of slightly acidic electrolyzed water against pure cultures of Escherichia coli and Staphylococcus aureus, in comparison with that of other food sanitizers. Food Control., 21: 740-745

Koide, S., J. Takeda, J. Shi, H. Shono and G. G. Atungulu 2009 Disinfection efficacy of slightly acidic electrolyzed water on fresh cut cabbage. Food Control., 20: 294-297

Lin, C-M., S. S. Moon, M. P. Doyle and K. H. McWatters 2002
Inactivation of Escherichia coli O157:H7, Salmonella enterica Serotype Enteritidis, and Listeria monocytogenes on Lettuce by Hydrogen Peroxide and Lactic Acid and by Hydrogen Peroxide with Mild Heat. J. Food Protect., 65: $1215-1220$

Mead, P. S., L. Slutsker, V. Sietz, L. F. McCaig, J. S. Bresee and C. Shapiro 1999 Food-related illness and death in the United States. Emerg Infect Dis., 5: 607-625

Nguyen-The, C and F. Carlin 1994 The microbiology of minimally processed fresh fruits and vegetables. Crit Rev Food Sci., Critical Reviews in Food Science and Nutrition 34: 371401

Okamoto, M., Y. Komagata, S. Okuda, Y. Nishimoto, M. Kamoshida and T. Nakamura 2006 Microbicidal effect of slightly acidic electrolyzed water. Bokin Bobai., 3: 3-10 (In Japanese)

Ono, T., M. Miyake and K. Yamashita 2005 Sterilization effect on vegetables by weak acid hypochlorous water to which a nonionic surfactant was added. J. Antibact Antifun Agents., 33: 257-262 (In Japanese)

Pfaller, M. A., I. Mujeeb, R. J. Hollis, R. N. Jones and G. V. Doern 2000 Evaluation of the discriminary powers of the dienes test and ribotyping as typing methods for proteus mirabilis. J. Food Microbiol., 38: 1077-1080

Rahman, S. M. E., T. Ding and D-H. Oh 2010 Inactivation effect of newly developed low concentration electrolyzed water and other sanitizers against microorganisms on spinach. Food Control., 21: 1383-1387

Rico, D., A. B. Martin-Diana, J. M Barat and C. Barry-Ryan 2007 Extending and measuring the quality of fresh-cut fruit and vegetables: a review. Trends Food Sci Tech., 18: 373-386

Sapers, G. M. 2001 Efficacy of washing and sanitizing methods for disinfection of fresh fruits and vegetable products. Food Technol. Biotechnol., 39: 305-311

Soli, K. W., A. Yoshizumi, A. Motomatsu, M. Yamakawa, M. Yamasaki, T. Mishima, N. Miyaji, K. Honjoh and T. Miyamoto 2010 Decontamination of fresh produce by the use of slightly acidic hypochlorous water following pretreatment with sucrose fatty acid ester under microbubble generation. Food Control., 21: 1240-1244

Suzuki, K., T. Nakamura, T. Doi, S. Kokubo and M. Tomita 2005 The disinfectant effect of slightly acidic electrolyzed water prepared with hydrochloric acid as a raw material for lettuce. J. Antibact Antifun Agents., 33: 589-597 (In Japanese)

Takano, M., and M. Yokoyama 2001 Practice of food disinfection (Part 1). In M. Takano and M. Yokoyama (Eds.) "Inactivation of food-borne microorganisms", (2nd ed.), Tokyo: SaiwaiShobo Press, pp. 261-313

Yamashita, S., M. Kato, S. Akiyama, H. Koike, H. Numao, M. Komachiya, N. Terashima and M. Ito 2005 Application of slightly acidic hypochlorous acid water to the dental field setting expansion and compressive strength of dental gypsum mixed with slightly acidic hypochlorous acid water. $J$. Jap. Prost. Soc., 49: 716-725 (In Japanese)

Yoshifumi, H. 2003 Improvement of the electrolysis equipment and application of slightly acidic electrolyzed water for dairy farming. J. Jap. Soc. Agri. Mach., 65: 27-29 